\title{
Free Will Ruled by Reason - Pufendorf on Moral Value and Moral Estimation
}

\author{
Katerina Mihaylova \\ Martin-Luther-University Halle-Wittenberg, Germany \\ katerina.mihaylova@phil.uni-halle.de \\ ORCID: 0000-0002-2646-9179
}

\begin{abstract}
Pufendorf makes a clear distinction between the physical constitution of human beings and their value as human beings, stressing that the latter is justified exclusively by the regular use of the free will. According to Pufendorf, the regular use of free will requires certain inventions (divine as well as human) imposed on the free will and called moral entities. He claims that these inventions determine the moral quality of a human being as well as the standards according to which human beings and their actions are able to be judged. This article examines the normative aspects of Pufendorf's concepts of moral value and moral estimation in regard to the epistemological question of the accessibility of moral entities for human beings. In the first part, it reconstructs Pufendorf's doctrine of moral entities and the place of moral estimation in this doctrine. In the second part, it presents Pufendorf's account of the moral philosophy as a science in order to explain his theory of moral normativity as imposed, and the role of a person in regard to their own moral status. In the last part, it illustrates some consequences in regard to the problem of slavery in Pufendorf.
\end{abstract}

\section{Keywords}

Pufendorf; conscience; estimation; natural law; human dignity; slavery

\section{Acknowledgments}

An earlier version of this paper was presented at the Esteem and Self-Esteem conference organized by Andreas Blank at the University of Klagenfurt in 2019. The present version has benefited from the comments of anonymous referees for this journal for which I am very grateful. I would like also to thank John Walsh and especially Anna Ezekiel for helpful remarks and copyediting. Work on this paper was generously funded by the German Research Foundation (DFG) project number 417359636. 
There are two functions by which, according to Samuel Pufendorf, human beings are determined by their nature: First, the desire for self-preservation, and second, self-esteem. The first is not specific to human beings and it is function of the instinct of nature. The second is based on the specific rational constitution of human beings as capable of regulating their actions and life in communities, which initiates the idea of the dignity of human nature. In the short compendium of his natural law theory, De officio hominis et civiis (1673), Pufendorf claims that the very sensitivity to one's own worth as a human being initiates the idea of human dignity and the idea of the equality of human nature: "Man [...] has of Himself also so nice an Estimation and Value, that to diminish any thing thereof does frequently move in him as great Indignation, as if a Mischief were done to his Body or Estate. Nay, there seems to him to be somewhat of Dignity in the Appellation of Man: so that the last and most efficacious Argument to curb the Arrogance of insulting Men, is usually, I am not a Dog, but a Man as well as your self' (OHC I.7.1). ${ }^{1}$ Pufendorf makes here a clear distinction between the physical constitution of human beings and their value as human beings, stressing that the latter is grounded exclusively in the regular use of the free will: "The Inference we ought to make from hence is, that we do not over-value ourselves with regard to others, considering that they equally with us are endowed with a free Use of their Understanding, which they are also capable of managing to as good Purpose; the regular Use whereof is that alone which a Man can call his own, and upon which the true Value of Himself depends” (OHC I.7.5). ${ }^{2}$ According to Pufendorf, the regular use of free will requires certain inventions (divine as well as human) imposed on the free will and called moral entities. ${ }^{3}$ He introduces the doctrine of moral

\footnotetext{
${ }^{1}$ Samuel Pufendorf, The Whole Duty of Man, According to the Law of Nature, transl. by Andrew Tooke, 1691, edited and with an introduction by Ian Hunter and David Saunders, Indianapolis: Liberty Fund 2003, p. 100.

2 "Per quam efficitur, ut nos nemini praeferamus, reputantes, caeteros aeque bene suo libero arbitrio, ac nos, uti posse, quo aequo pollent; cujus legitimus usus unicum illud est, quod homo pro suo reputare possit, \& quo sese aestimare aut despicere queat." (Pufendorf, De Officio hominis et civiis, Stockholm 1702, p. 136) In his English translation, Andrew Tooke uses "a free use of their Understanding" for the original "suo libero arbitrio" and "the regular use whereof” for the original "cujus legitimus usus" (Pufendorf, The Whole Duty of Man, p. 103). This decision of the translator (to translate "free use of the understanding" instead of "free will") could be explained by the consideration that for Pufendorf the free will always uses the understanding, which leads the will, like a torch leads a person in the dark (see JNG I,3.3), which in this way makes it free. It is remarkable that Pufendorf claims the rational conduct of free will to be "that alone which a Man can call his own" and that a person's value as a human being is founded in this exclusive property. It seems likely that John Locke, who follows Pufendorf very closely, adopts and extends this idea of value, claiming in his Second Treatise on Government that there is a property in our own person, namely the "property of labour", which is exclusively ours and "puts the difference of value on every thing" (John Locke, Two Treatise of Government, ed. by Peter Laslett, Cambridge 1988, p. 296).

${ }^{3}$ Pufendorf's idea that the regular use of free will (and therefore value) is due to imposition by (divine) will implies some conceptual queries, which Stephen Darwall identifies as a kind of deficiency of Pufendorf's theory.
} 
entities in the first book of his De jure naturae et gentium, where he claims at the very beginning that these inventions also determine the moral quality of human being as well as the standards according to which human beings and their actions are able to be judged. which is the moral quantity (JNG I.1.2). As Jerome Schneewind points out, this doctrine offers "a new response to the developing scientific view of the world as neutral with respect to value". ${ }^{4}$

This paper examines the normative aspects of Pufendorf's concepts of moral value and moral estimation in regard to the epistemological question of the accessibility of moral entities for human beings. In the first part, it reconstructs Pufendorf's doctrine of moral entities and the place of moral estimation in this doctrine. In the second part, it presents Pufendorf's account of the moral philosophy as a science in order to explain Pufendorf's theory of moral normativity as imposed and the role of a person in regard to the own moral status. In the last part, it illustrates some consequences in relation to the problem of slavery in Pufendorf.

\section{Pufendorf on the Place of Moral Estimation within the Doctrine of entia moralia}

At the beginning of his work De jure naturae et gentium, Pufendorf states that Aristotelian metaphysics has been very helpful for the exploration of nature, since it delivers proper conceptual instruments for the systematic classification of natural entities and for the examination of the principles on which nature is based: "It was the Business of the First and Highest Philosophy, and that by which alone it could fully answer the Design of its Name, and Institution, to deliver the most Comprehensive Definitions of

According to Darwall, Pufendorf is using a circular argument: "we encounter a fundamental instability, since the idea of 'moral power' as Pufendorf understands it seems already to presuppose a fundamentally equal sociability, dignity, and right, where Pufendorf seeks to derive these equal moral powers from God's superior moral power" (Stephen Darwall, "Pufendorf on Morality, Sociability, and Moral Powers", in: Journal of the History of Philosophy 50/2 [2012], pp. 213-238, here p. 237). As I will argue in this paper, there are two perspectives in Pufendorf's theory: an ontological one and an epistemological one, where the second is the fundamental one. According to my interpretation there are some misunderstandings of Pufendorf's theory due to the overemphasis on the ontological perspective. The consequence of my interpretation is that I do not share Darwall's attestation (which is a common interpretation) that natural law and morality in Pufendorf is founded merely on God's use of moral power. This, according to Darwall (and other interpreters of Pufendorf), is in opposition to Grotius and Hobbes, who claim the foundation of natural law and morality in rational self-interest. I will argue in this paper that Pufendorf's theory implies both aspects (rational self-interest and theological voluntarism) and that the difference is not fundamental but rather due to different perspectives of argumentation (an epistemological one and an ontological one).

${ }^{4}$ Jerome B. Schneewind, The Invention of Autonomy. A History of Modern Moral Philosophy, New York: Cambridge University Press 1998, pp. 138-139. 
Things, and to rank them agreeably under the proper Classes, subjoyning the General Nature and Condition of every Sort of Beings.”5 (JNG I.1.1) But Pufendorf also states that the conceptual instruments of Aristotelian metaphysics are not sufficient for the examination and classification of moral entities, which are not given by nature but are something artificial, produced by human beings: “[...] it is evident, that Man have not been equally solicitous about the Constituting the Entia Moralia, or Moral Entities, nor treated them with the Respect which their Dignity require'd. ${ }^{6}[\ldots]$ it was highly expedient, that they should be fully understood by Mankind, who are endu'd with the Power of producing them, and through whose whole Lives and Conducts their Force and Activity is diffus'd” (JNG I.1.1). Moral philosophy (as the discipline about such artificial entities produced by mankind) should develop conceptual instruments similar to, but separate from, those in Aristotelian metaphysics, which are proper for the investigation of moral entities.

According to Pufendorf, moral philosophy should also explore the normative standards according to which the will is able to produce moral entities or be determined by them. Pufendorf describes the process of production of moral entities with the term imposition: "Our Business is to declare, how, chiefly for the Direction of the Will, a certain Kind of Attributes have been impos'd on Things and their Natural Motions; whence there springs up a peculiar Agreement and Conveniency in the Actions of Mankind, a grateful Order and Comeliness for the Ornament of Human Life. And these Attributes are call'd Moral Entities, because the Manners and the Actions of Man are judg'd and temper'd with relation to them; and do hence assume a Face and Habit different from the horrid Stupidity of the dumb Creation” (JNG I.1.2).

Moral philosophy has to explore such attributes (1) in order to deliver the standards for moral conduct of human actions; and (2) in order to deliver the standards for judgements about moral entities. Such exploration of moral entities requires a metaphysical foundation enabling a systematic

\footnotetext{
${ }^{5}$ Samuel Pufendorf, Of The Law of Nature and Nations. Eight Books, transl. Basil Kennet, London 1717. In the following, I use this English translation.

${ }^{6}$ Kari Saastamoinen claims human dignity as expressing "a comparative superiority in relation to other creatures” (Kari Saastamoinen, "Pufendorf on Natural Equality, Human Dignity, and Self-Esteem”, in Journal of History of Ideas, Vol. 71/1 (2010), pp. 39-62, here p. 41). I agree with that but with the reference that such comparative superiority is due to the capability to understanding and to free will and therefore to moral conduct. According to Pufendorf, human dignity is always linked to and justified by the participation in the realm of moral entities.
} 
categorization of moral entities and exploration of the principles on which they are based. Pufendorf does not use formulations like metaphysics of morals or metaphysical foundations of morals for his claim. ${ }^{7}$ However, since moral entities are not self-contained but rather impositions on natural entities (see also JNG I.1.4), he suggests that the conceptual foundation of moral philosophy should be organized by analogy to Aristotelian metaphysics and its analysis of the constitution and principles of natural entities. It even seems at first sight that Pufendorf's theory of moral entities is embedded in Aristotelian metaphysics, claiming moral entities to be "contradistinguished to [the] substance" of natural entities and added to the latter by "understanding beings," so that moral entities can be described as modes of natural entities that are not self-subsistant (JNG I.1.3). The very definition that Pufendorf gives ${ }^{8}$ seems to suggest that, in regard to causality, moral entities are something like practical reasons. He avoids conceptualizing them in Aristotelian terms but points out that there is a fundamental difference between natural entities and moral entities due to the fundamentally different causality of their internal force. ${ }^{9}$

Pufendorf claims that natural entities and moral entities differ not only in their constitution (being created in the case of natural entities or being imposed in the case of moral entities), but also in the internal force which causes their motions: "All the Beings which compose this Universe [...] have every one of them their particular Properties, arising from the Disposition and Aptitude of their Substance, and exerting themselves in agreeable Actions, according to the[ir] Portion of Strength [...]. These Properties we usually call Natural, since the Term Nature hath been extended so far as to denote, not only the General Mass of Things, but also the Modes and Acts flowing from the internal Force of

\footnotetext{
${ }^{7}$ In prominent research on Pufendorf there are controversial interpretations of whether Pufedorf's claim entails metaphysical aspects or not. On the one side there are positions like that of Ian Hunter, who opposes Pufendorf's project to metaphysical claims, but stresses this in regard to political theory: "We cannot appreciate the true character of Pufendorf's reconstruction of ethics and politics until we realise that he is no longer in the business of attempting to derive political obligation via metaphysical reflection on man's rational and moral being. [...] Pufendorf was among the first to see that the desacralisation of civil governance meant that individuals would have to learn to accede to their civil duties independently of cultivating an 'integral' moral personality - a practice which would have to be restricted to the domain of private spiritual striving." (see Ian Hunter, Rival Enlightenments. Civil and Metaphysical Philosophy in Early Modern Germany, Cambridge: Cambridge University Press 2001). On the other side there are interpretations of Pufendorf as providing his own "metaphysics of ethics" (see for example Schneewind, Invention of Autonomy, p. 138).

8 "We may define Moral Entities to be certain Modes superadded to Natural Things and Motions, by Understanding Beings; chiefly for the guiding and tempering the Freedom of voluntary Actions, and for the procuring of a decent Regulatory in the Method of Life.” (JNG I.1.3)

${ }^{9}$ It is not very clear, whether Pufenorf is using the Aristotelian doctrine of the four causes when he claims in JNG I.1.2 a difference between the causality of the internal force of instinct of nature and of the human free will. I will consider this difference below.
} 
their Constitution, by which is produc'd that infinite Variety of Motions which turns and manages all the Business of our World. Those Things which exercise their Operations, either without any Sense at all, or with pure drown-right Sense, or with such as is assisted by very imperfect Reflexion, are guided by the sole Instinct of Nature, and are unable to govern their Actions by any Rule or Mode or their own Invention" (JNG I.1.2). Natural entities can have an internal force that causes movements, which is the instinct of nature. But this kind of internal force cannot be called moral because it is not regulated by norms. Unlike animals, for Pufendorf, human beings have in addition to their natural instinct also the capability of self-regulation of their motions following reasons and using and creating rules, which is due to the cooperation of the higher faculties of understanding and free will. ${ }^{10}$ This idea Pufendorf shares with Grotius, who also claims the capacity to act according to rules as a quality of the human being.

For Pufendorf, the capacity of finding out and inventing rules is not in the first instance an instrument for conducting actions, but primarily for improving the conduct of the human faculties (understanding and will): "But Man, who beside his excellent Form and most accurate Contexture of Body, fitting him for the noblest and the quickest Offices of Life and Motion is endu'd with a singular Light of Understanding, by the help of which he is able most exactly to comprehend and to compare Things, to gather the Knowledge of Obscurities, from Points already settled, and to judge of the Argument which Matters bear to each other; and has also the Liberty of exerting, suspending, or moderating his Action, without being confin'd to any necessary Course or Method: Man, we say, is farther invested with the Privilege of inventing and applying new Helps to each Faculty, for the more easy Regulation of its Proceedings.” (JNG I.1.2)

The attributes, which are imposed on the natural movements (thinking and desiring) of the higher human faculties (understanding and will), and which modify them in an artificial way, have the purpose of initiating and supporting rationality in human thought and desire, providing and improving organization in their procedures. This artificial modification of the human faculties seems to transform the quality of understanding by establishing rules for thinking (logic) and the quality of free will (and free actions) by establishing rules for free will (morals). Pufendorf claims this transformed quality of

\footnotetext{
${ }^{10}$ This cooperation leads to the formulation "regular use of the free will", which Pufendorf uses in order to mark the crucial criterion for the concept of value (see footnote 3 and once more OHC I.7.5 and also JNG I.1.2).
} 
free will to be the moral quality of persons and of their actions. Without such artificial modification the free will can follow, moderate, or suspend the natural desires (which are determined by instinct of nature), but artificial modifications lead to regulation of this activity of free will. This regulation is achieved or invented by reason as one of three general sources for derivation of norms: "Now 'tis very manifest, that Men derive the Knowledge of their Duty, and what is fit to be done, or to be avoided in this Life, as it were from three Springs” (OHC Preface) - one of these is reason (ex lumine rationis) ${ }^{11}$, another is the positive laws (ex legibus civilibus), and a third is theological sources (ex peculiari revelatione). ${ }^{12}$

In light of all this, it seems to follow that Pufendorf demands for moral philosophy a conceptual foundation that is entirely separated from the conceptual foundation of Aristotelian metaphysics, but is still built by analogy to it (JG I.1.5, see also I.1.6-7). ${ }^{13}$ According to Pufendorf, from the perspective of Aristotelian metaphysics (which is metaphysics of natural entities), there is a difference between substances and their modes, where only natural entities can be understood as substances and moral entities are merely to be defined as modes of natural entities. From the perspective of the required theory of moral entities there is an analogical difference between moral substance and moral mode. The analogical concept to substance is the person (JNG I.1.12), but it is not identical with the human being as a natural entity, and the two possible modes of the person (the moral quality and the moral quantity) are not identical with the modes of natural entities.

\footnotetext{
${ }^{11}$ Ibid. Once again, the English translation from 1715 offers peculiar interpretation while translating "ex lumine rationis" with "from the light of nature". A possible explanation for this could be the consideration of the content of thinking and willing (which is experience and natural desires) and not of the artificial regulation of the faculties of understanding and free will (which is invention imposed to these faculties).

${ }^{12}$ In the Preface of his Discours sur l'inégalité (1755), Jean-Jacques Rousseau acknowledges Pufendorf for differing between rules which nature follows, and rules which nature prescribes to rational beings, and claims this distinction as a merit of early modern philosophy in contrast to ancient philosophy. But Rousseau accuses Pufendorf of providing a metaphysical account of epistemic access to the rules nature prescribes, instead of acknowledging the instinct of nature as the actual source of such normativity. Rousseau's critique of Pufendorf's moral epistemology seems to imply a deficient understanding of the function of the fundamental difference between natural entities and moral entities in Pufendorf. However, Rousseau has reasons for this critique. As Schneewind points out, Pufendorf is claiming that every mature person is able to "comprehend at least the more general precepts" (JNG I.3.3), but more detailed knowledge is a privilege of authorities (JNG II.3.13: see Schneewind, Invention of Autonomy, p. 126).

13 “[...] ad normam entium physicorum ista quoque moralia in classes redigere. Idque tum quia in illa majori studio inquisivere philosophi, sic ut ex eorundem comparatione hisce multum lucis accedere possit; tum quia vix aliter quam ad analogiam entium physicorum intellectus noster materiae immersus moralia concipere valet.”
} 
According to Pufendorf, every human being could be a natural entity and a moral entity at the same time. But the division is essential and the comparison just analogical. In the classification of moral entities, persons can be analyzed in regard to the different aspects (unrestricted and restricted) of their moral states. On the one hand, a moral state can be unrestricted insofar it is thought as a natural moral state or as a contingent moral state. ${ }^{14}$ The moral state is natural insofar as the moral person has an essential state (the predisposition to rationality and the capacity for self-regulation as an essential property) and insofar as the moral person has a relational state (it is equal in its relation to other moral persons regarding the essential properties of others). ${ }^{15}$ The state is contingent insofar as the moral person is married, has relatives, is part of certain hierarchies etc. On the other hand, there are some possible restrictions of the natural moral state of a person, such as age or majority, which implicate the temporal restriction or obstruction of the use of the predisposition to rationality (for example at a very young age, when the child needs the care of its parents or in case of mental illness). Such restrictions form, according to Pufendorf, the restricted moral state of a person. ${ }^{16}$

\footnotetext{
${ }^{14}$ Here it is possible to exemplify that the relation between natural and moral entities is just analogical one: When Pufendorf differentiates between the natural moral state and the contingent moral state of a person, he is pointing out that the natural moral state is not the state of natural entities before every imposition of moral entities ("Naturalem hominis statum vocamus, non quod is citra omnem impositionem ex physicis principiis essentiae humanae fluat” JNG I.1.7). Instead, he is claiming it as the state resulting from the imposition of some (divine) reason different to impositions made by human beings ("sed quod ex impositione Numinis, non ex arbitrio hominum, hominem statim ab ipsa nativitate comitetur." [JNG I.1.7]). This specification also points out the difference between creation (natural entities) and imposition (moral entities) on the level of divine action. But this perspective should also be separated from the epistemological one of acknowledging the rules of reason as divine impositions or divine commands, which determines the difference between prudential and moral rules in Pufendorf. I will discuss this in the second part of this paper noting Pufendorf's critique of Aristotelian moral philosophy as failing to attain the status of science.

${ }^{15}$ John Locke states something similar when he defines the state of nature in his Second Treatise of Government not only as a "State of perfect Freedom" but also as a state "of Equality" in Power and Jurisdiction due to being part of "the same species" and being "born [...] to use the same faculties" (John Locke, Two Treatise of Government, ed. by Peter Laslett, Cambridge 1988, p. 269; see also p. 304). In Pufendorf, this relational aspect of the natural moral state is also seen by some researchers as the foundation of the duty for respect and humanity, which leads to the difference between Pufendorf's concept of the natural state and that of Hobbes (see: Otto Dann, Gleichheit und Gleichberechtigung. Das Gleichheitspostulat in der alteuropäischen Tradition und in Deutschland bis zum ausgehenden 19. Jahrhundert, Berlin 1980, p. 98).

${ }^{16}$ The possibility of restriction of the natural state is also included in Locke's discussions of (1) the state of war (and slavery), (2) property, and (3) paternal or parental power (Locke, Second Treatise, pp. 278-318). In the first case, a person harming the law of nature is no longer "under the ties of the Common Law of Reason" and "has no other Rule, but that of Force and Violence, and so may be treated as Beasts of Prey, those dangerous and noxious Creatures" (ibid., pp. 279). In the second case, a person uses their natural freedom to create "Property in his own Person": the person is able in this way to remove something "out of the State of Nature" by using "the Labour of his Body, and the Work of his Hands" and to make "it his Property" (Ibid., p. 287-288). Third, Locke discusses the case where someone could be temporary under the subjection of another analyzing the status of children who "are not born in this full state of Equality, though they are born to it” (ibid., p. 304).
} 
Beside the person and its moral state, the moral modes are the other important part of the classification of moral entities. The moral modes signify two ways, in which the person is related to moral attributes: their moral quality and their moral quantity. Moral quality is the mode in which the person is affected by moral attributes (rules derived by reason) and moral quantity is the mode in which the person is judged according to moral attributes (JNG I.1.17). ${ }^{17}$

The mode of moral quality, which Pufendorf also calls the mode of moral affection, includes formal qualities expressing moral attribution (JNG I.1.17 and I.1.18) and operative qualities expressing the ability to be affected by moral attributes or the ability to affect through moral attributes (JNG I.1.17 and I.1.19-20). The formal qualities include simple attributions like titles expressing general respect and honor, such as serenity or eminence, titles of power and authority, titles of office and rights, but also titles serving as a compliment. The operative qualities can be, first, primitive qualities concerning the internal or external ability to be affected by moral attributes, which Pufendorf also calls passive operative qualities, insofar as they include the passive part of the affecting relation, such as being obligated though norms. Second, the operative qualities can be derived qualities, which concern the active part of the affecting relation and include the ability to obligate someone (which is defined as having power), the ability to justify moral affection (which is defined as having a right), or the obligation itself (which is defined as a moral necessity of actions).

The second mode is moral quantity or the mode of moral estimation (JNG I.1.17 and I.1.22). This is the mode in which the relation between the moral person and moral attributes (in which the former is affected by the latter) is an object of moral judgement about moral worth. This relation implies regard to (1) to the person itself, (2) their actions or (3) objects of trade between different persons. The notions testifying to moral worth in such moral judgements are (1) esteem in regard to persons and (2) price in regard to objects. Essential for judgements about moral worth is the consideration of moral

\footnotetext{
17 "Videntur autem modi commodissime posse distribui in affectivos, et aestimativos: secundum illos personae certa ratione affectae intelliguntur, secundum hoc personae et res aestimari aptae sunt.” It is significant here that Pufendorf is using the term "affection" and not "determination", since this gives us an idea of what he claims the effects are of the recognition of moral entities. There seems to be a lack of sensitivity in regard to this formulation. For example Schneewind states that Pufendorf "offers no account of how a recognition of a moral entity can have effects in the physical world" (Schneewind, Invention of Autonomy, p. 138). But it seems to be clear that such an effect is thought merely as an affection and as such it has the binding force of advice or counsel and can oblige the free will to a certain action only if the person, who recognizes the affect as given by reason, is consequent enough to recognize it also as the will and command of God. I will discuss this aspect in the next part of the paper.
} 
value. At the very beginning, we already pointed out that Pufendorf explicitly claims that moral value is depending in an essential way on the regular use of the free will. We also pointed out that such regular use requires an affecting of a person by moral attributes in order to achieve free causality different from the causality of the instinct of nature. We also saw that Pufendorf calls the ability to be affected by moral attributes the primary moral quality and the ability to affect by moral attributes the derived moral quality (i.e., derived from the former). In the following part of the paper, we will first explain how, according to Pufendorf, the mere affecting by moral attributes becomes an imposition, which is how Pufendorf claims moral obligation emerges and which refers to the epistemological perspective of the obliged person. Second, we will explain how exactly this is connected with moral worth and moral estimation.

\section{Pufendorf's Theory of Moral Estimation}

Pufendorf requires moral philosophy to come up to scientific standards ${ }^{18}$ based on demonstration and claims it to be an alternative to Aristotelian ethics. According to Puffendorf, Aristotle claimed that honesty and justice "fell under the consideration of Civil Knowledge, have so many different Faces, and are liable to so many Mistakes, that they seem to be only instituted by Law, and not originally directed by Nature” (JNG I.2.1). Pufendorf instead agrees with the claim of Stoic philosophy that moral principles are not given by agreement, contract, and positive laws, but are derived from human nature. He also accuses philosophers like Aristotle of being satisfied with probable knowledge about morality: "The foundation of their Notion is this: they take Morality to be incapable of Demonstration, from whence only true Science, and free from the fear of Error, can proceed, but imagine that all its evidence rises no higher than a Probable Opinion” (JNG I.2.1). In contrast to mathematical knowledge which operates with axioms and demonstrations, an Aristotelian model of moral knowledge proceeds, according to Pufendorf, merely descriptively and for that reason there is no axiomatic foundation for the demonstration. Demonstration always requires the explanation of a result by tracing it back to a fundamental first principle and making explicit the causal relation between them. (JNG I.2.3).

\footnotetext{
18 "Knowledge of the Law of Nature, [...], which includes all Moral and Civil Doctrins that are genuine and solid, to make this Knowledge, we say, fully come up to the Measure and Perfection of Science”. (JNG I.2.8)
} 
Pufendorf claims that his idea of moral philosophy, expressed by his natural law theory, is able to achieve evident knowledge: "Hence in Prudential Managements most Men think it sufficient to follow that Rule of Aristotle [...] As for the former and more noble Species, which we assign'd to Moral Disciplin, that which considers what is Right, and what Wrong in Human Actions, the best Share of which will be illustrated in our present Attempt; this is built altogether on so sure Grounds, that we thence draw genuine Demonstrations, able to produce true and solid Science. Or, in other words, its Decrees may be in such a Manner derived from certain Principles, as to leave no Room, no Excuse for Doubt. Whatever contributes to the improving of our Virtue, or of our Happiness, Nature hath taken care to lay either directly before us, or at a very easy distance for our Search” (JNG I.2.8).

Pufendorf presents a very clear description of his methodology in the chapter Of the Law of Nature in General (OHC I.3). The empirical experience of human nature is the starting point for the derivation of a prudential rule for human actions (sociability). The necessity of this prudential rule is a merely hypothetical one depending on whether or not the acting person confirms and adopts the end of human nature or not. It becomes a moral rule (with categorical necessity) only once the end of human nature has been traced back to the necessity of a divine will which the acting person recognizes as authority (and as prima ratio of human nature). This is how the rule becomes an imposition. This moral rule is then the principle from which three kinds of natural obligation can be derived: a natural obligation first to God, second to its own self, and third to other human beings. This procedure is the construction of the natural state ${ }^{19}$ of human beings. ${ }^{20}$ The crucial point for understanding Pufendorf's methodology

\footnotetext{
${ }^{19}$ Pufendorf points out that when he uses the term natural state in regard to human beings, he is referring not to natural entities before every imposition, but rather to the state of imposition of (divine) reason before every (human) contingent imposition: "Naturalem hominis statum vocamus, non quod is citra omnem impositionem ex physicis principiis essentiae humanae fluat; sed quod ex impositione Numinis, non ex arbitrio hominum, hominem statim ab ipsa nativitate comitetur." (JNG I.1.7; see also footnote 14 of this paper). The state of initially imposed (divine) reason mentioned here is the inevitable sociability of human beings as the principle of moral attribution (in respect to natural law). But despite this strict conceptual division, there is still the epistemological perspective in Pufendorf, in which empirical perceptions and observations of natural entities are important starting points for the rational derivation of the imposed (divine) reason in human nature. But Pufendorf abstains from achieving knowledge of the intentions of God as such. For him, it is not possible to derive this from empirical observations of God's creation. For this epistemological perspective in Pufendorf, see Horst Denzer, Moralphilosophie und Naturrecht bei Pufendorf, Munich: Beck 1972, pp. 40-49; on the function of empirical observation see especially p. 48. Ian Hunter suggests an interpretation of the epistemological account of Pufendorf concerning the observation of "the requirements of the exigent condition in which" the reflecting person "happened to find himself" (Ian Hunter, "The invention of human nature: the intention and reception of Pufendorf's entia moralia doctrine”, in: History of European Ideas 45/7 2019, pp. 933-952.). ${ }^{20}$ I already mentioned in the first part of this paper that within his doctrine of moral entities Pufendorf defines the rationality of a person as the essential property of natural state. Some researchers claim the method of construction of this natural state is a resolutive-compositive one (see Hans Medick, Naturzustand und
} 
is the account first of the difference and second of the interdependence between what he claims here as a prudential aspect of normativity and what he claims as a moral aspect of normativity. With the prudential aspect, we are regarding the benefit (or utility) of a rule "for the general Good". With the moral aspect, we are regarding the prescriptive character of a rule as a law, which, according to Pufendorf, should be thought as a command of a superior (in the case of natural law it is the command of God) for the sake of "the Government of the other" (OHC I.3.9). Both aspects are thought in a relation of interdependence. While the prudential aspect provides the reason for the natural law (the utility of sociability for the safety and common benefit of humankind), the moral aspect provides the validity of natural law (the imposition or why it is necessary to suppose a superior) (OHC I.3.10). ${ }^{21}$

Considering this difference and interdependence between prudence and morals in Pufendorf, we could understand the relation between natural right and natural law in Pufendorf and their function for the initiation of moral value. As we mentioned at the beginning, Pufendorf points out that moral value is grounded exclusively in the ability of a person to regularly use the free will. This subjective condition implies two accomplishments of the person: (1) the cognition of the reason according to which the free will should be regulated, and (2) the acknowledgment of the reason as an imposition binding the free will. According to Pufendorf, prudence enables the "dexterous government of actions for security and benefit”, which is our natural right provided by reason and grounded in human nature. This cognitive ability is the first subjective condition of moral value, but it obliges only hypothetically as counsel (if you want security and benefit, you should follow the rule). The second subjective condition is therefore the ability to be obligated, which also implies a cognitive aspect. Without insight into the

\footnotetext{
Naturgeschichte der bürgerlichen Gesellschaft: die Ursprünge der bürgerlichen Sozialtheorie als Geschichtsphilosophie und Sozialwissenschaft bei Samuel Pufendorf, John Locke und Adam Smith, Göttingen 1973, p. 31; see also the further analysis in Wolfgang Röd, Geometrischer Geist und Naturrecht: methodengeschichtliche Untersuchungen zur Staatsphilosophie im 17. und 18. Jahrhundert, München 1970). Medick points out that the methodology in early modern natural law based on the construction of natural state as an analytical-normative axiom is crucial for the normative claim of natural law and political theory of that period (Medick, Naturzustand und Naturgeschichte, p. 39). Röd provids an impressive analysis of Pufendorf's methodology which also helps understand the relevance of Erhard Weigel's application of mathematical methods in social disciplines to Pufendorf's own methodology, which leans on Weigel's but develops it further.

${ }^{21}$ On the one hand Pufendorf links the prudential aspect to the will of God: “And since he that designs the End, cannot but be supposed to design those Means without which the End cannot be obtain'd, it follows that all such Actions as tend generally and are absolutely necessary to the Preservation of this Society, are commanded by the Law of Nature” (OHC I.3.9). On the other hand, he suggests that in human reason there is already a necessity to observe prudential reasoning as if it is a law: "He has enjoyn'd us Mortals, to observe these Dictates of our Reason as Laws [...] to the Constitution of which a Superior is necessary to be supposed” (OHC I.3.10).
} 
categorical necessity of the reason, due to the command of a superior (the will of God as the prima ratio for the constitution of human nature), natural rights alone are not capable of providing moral normativity (natural law) for the regulation of free will. There will be no moral obligation or moral value.

These two subjective conditions for the regular use of free will are both essential for Pufendorf's concept of moral obligation. In regard to the capability of being obligated, Pufendorf refers first to the ability to understand a rule and secondly to the ability to conform one's own action to a rule (OHC I.2.4). Because both are efforts or accomplishments of the acting person, Pufendorf explicitly points out that his definition of obligation is different from that of Cumberland, who defines it as a command of a superior. Pufendorf claims obligation rather as an active moral quality of the acting person being able to respect the command of superior. ${ }^{22}$ The command of a superior (which is the moral power or ability to obligate) is still an essential ontological condition for the concept of obligation. But, as we already mentioned above, Pufendorf claims this from an epistemological perspective. It is a derivation from the primal operative moral quality (which means from the moral power or ability to be obligated), but it is not sufficient for initiating obligation. Obligation is a result of the subjective reaction to the command of a superior, including the feeling of "Fear mixt with Reverence". Pufendorf stresses here the two grounds for this fear, which are both accomplishments of the obliged person. The mixed feeling of fear and reverence is due first to a consideration and second to a conviction: "the first arises from the consideration of his Power, the other proceeds from those Reasons on which the Authority of our Superior is founded; by which we are convinced, that had we nothing to fear from him, yet we ought to conform our Actions to his Will” (OHC I.2.5).

We saw that the derivation of both moral normativity and moral motivation depend on subjective conditions due to the intellectual faculties of human nature. We also saw that without them the regulation of the free will according to rules of reason would be impossible. And we mentioned that the latter is the foundation of moral value. Therefore, we may distinguish between two aspects of the morality of a

\footnotetext{
22 “Obligationem igitur supra definivimus, per qualitatem moralem operativa[m], qua quis praestare aut pati quid tenetur (quando nempe obligationem consideramus, prout haeret in eo, qui obligatur. Secus atque Rich. Cumberland de leg. nat. c.5. §.27. qui obligationem definit, prout est actus legislatoris, quo actiones legis suae conformes eis, quibus lex fertur, necessarias esse indicat).” (JNG I.6.5) This passage is not included in the first edition from 1672 because Pufendorf was not acquainted with Cumberland's work at that point. He added this passage in the second edition in order to explain the difference with Cumberland who held the command of a superior alone to be a sufficient condition for obligation ignoring the subjective accomplishment of the obliged person.
} 
person: (1) the ability to perform moral conduct, which is the foundation for the dignity of a person as a human being and should be always respected as inherent to the natural moral state of a human being; and (2) the use of this ability, which determines the actual moral state of a person and is the foundation of moral value und the object of moral estimation. We should now make clear how exactly the subjective accomplishments of a person are to be judged and according to which standards such estimation should proceed. Such standards concern first the morality of the actions of the person and second the intention of the person. In the first case, moral estimation is a judgement of a person about the actions of another person. Pufendorf allocates this kind of judgement to the human court or forum humanum (JNG I.8.3). In the second case, moral estimation is a judgement of a person about their own actions from the perspective of an ideal and impartial spectator. Pufendorf allocates this to the divine court of conscience or forum divinum (JNG I.8.2). ${ }^{23}$

For Pufendorf, the morality of the actions of a person (judged in the forum humanum) could be estimated according to standards such as (1) their moral necessity, i.e., dependence on the command of a superior, (2) their goodness, i.e., accordance with the command of superior, and (3) their justice, i.e., observance of the natural rights of other persons ${ }^{24}$ (JNG I.7.1-3, and I.7.7; see also OHC I.2.12-13). This conceptual specification allows Pufendorf to distinguish between absolute estimation, which is estimation according to the standard of goodness, and estimation about excellence, which is estimation according to the standard of justice. In regard to civil law, it is possible that (1) and (2) are in opposition to (3), which means that a person could act morally and good, but unjustly. ${ }^{25}$ In regard to natural law, such opposition is not possible, since the understanding of the natural law as a command of God entails

\footnotetext{
${ }^{23}$ In a paper on the development of the concept of the forum internum in the German Enlightenment, I argued that Pufendorf's account of the forum divinum, as a Protestant critique of medieval concepts of conscience, should be understood as an enlightened requirement attempting to support practical rationality in human behavior (which is the organization of one's own actions according to rules instead of following natural instinct). This implies that a constant judging of the accordance of the own actions with norms will increase such accordance and lead to habits of rational conduct (Katerina Mihaylova, "Gewissen als Pflicht gegen sich selbst. Zur Entwicklung des forum internum zwischen Pufendorf und Kant“, in: Gewissen. Interdisziplinäre Perspektiven auf das 18. Jahrhundert, ed. by S. Bunke and K. Mihaylova, Würzburg 2015, pp. 53-70). ${ }^{24}$ Grotius does something similar when (in the first two pages of the prolegomena to his De jure belli ac pacis) he criticizes the ancient understanding according to which justice could be understood as the right of the strongest. Grotius tries to clarify the fundamental difference between justice and the right of the strongest by explaining the difference between justice and utility: While utility always refers to an individual perspective which could possibly conflict with another individual perspective, justice should be considered as a universal norm with the purpose of regulating conflicting individual interests.

${ }^{25}$ Such a case would imply that the civil law deviates from the prescriptions of natural law. This enables critique of the civil law using natural law as the standard which the civil law must meet.
} 
the intention to observe of natural rights. This means that the actions of a person are either according to natural law and therefore moral, good, and just, or against natural law and therefore immoral, evil, and unjust. Actions of a person which are immoral, evil, and unjust give us in the state of nature the right to war and in the civil state the right to prosecution (JNG I.7.7).

The standard for the estimation of the intention of a person (judged mainly in the forum divinum) is the justice of the person. Pufendorf claims this as a virtue and adapts the Justinian's definition of justice of persons (“Iustitia est constans et perpetua voluntas ius suum cuique tribuendi”) which implies not only the virtue of the acting person, but also the moral requirement of respect towards the natural rights of other persons ("Justitia autem praeterea involvat respectum ad eos; in quos action exercetur. Quo nomine etiam Justitia virtus adversus alium dicitur”). When someone claims to respect the natural rights of other persons but does so not out of virtue but out of prudence (for example aiming at social esteem), he is, according to Pufendorf, not a just person (JNG I.7.6) and should be aware of the loss of self-esteem in their conscience. But according to Pufendorf, such loss of self-esteem seems not to impair the justice of the actions of this person, nor the social esteem which the person earns as a just acting person (not as a just person). ${ }^{26}$ The function of the judgements of conscience on self-esteem in the forum divinum seem to be merely a self-consciousness of the use of the ability for moral conduct, therefore of one's own moral worth. The neglect of conscience will sooner or later impair the moral quality of actions and therefore successful existence in society, which will then lead than to loss of social esteem. The improvement of the moral conduct of a person due to judgements about self-esteem seems therefore to be helpful for the purpose of morality as well as for the prudential purpose of personal happiness and wellbeing in a social context.

Now that we have discussed the normative frame of Pufendorf's concepts of moral value and moral estimation, we should finally consider some surprising consequences of these concepts in regard

\footnotetext{
${ }^{26}$ The idea that esteem and self-esteem have different functions is also present in contemporary debate (see for example Geoffrey Brennan and Philip Pettit, The Economy of Esteem: An Essay on Civil and Political Society, Oxford 2004). While Pufendorf seems to share the analysis of such modern theories in regard to the function and mechanisms of esteem in social and political life, he considers the concept of self-esteem in a different way, stressing its function in regard to the moral integrity of a person. However, my aim in this paper is not to analyze the psychological mechanisms of the social function of esteem and self-esteem in Pufendorf, but rather the theoretical frame and the normative standards according to which judgements about esteem and self-esteem are grounded.
} 
to moral estimation about objects, especially in cases where human being are regarded as objects as in the case of slavery.

\section{Pufendorf on the Possibility of Slavery}

We already saw that for Pufendorf moral judgements are classified as modes of moral persons and that such modes consist in moral quantification. There is moral worth that can be measured and it could relate to the person, their actions, or objects related to them. The moral worth of objects depends, according to Pufendorf, on how much they support the moral worth of a person (JNG V.2.6). However, one aspect of Pufendorf's discussion of the moral worth of an objects seems to be controversial: his discussion of the possibility of slavery, which allows persons to be treated as a property having the moral worth of objects. We will analyze two cases in which Pufendorf discusses this possibility and then examine what exactly Pufendorf is claiming in each case in regard to moral value and moral worth. ${ }^{27}$

The first case is that of what Aristotle describes as a slave by nature. Pufendorf criticizes this concept, claiming that there is no person who is determined by nature to slavery; instead, there is only difference in temperament between persons (JNG VI.3.2). Persons who tend to indolence and fatuity are neglecting their needs and in order to survive they need someone else to care for them. Therefore, they need to sign a contract with someone who is willing to give sustenance in return for some service. According to Pufendorf, such contractual agreement is the true origin of slavery (JNG VI.3.4). Slavery is therefore always a special relation of exchange, which is lifelong because of the special condition of the slave as not capable of surviving without the care of others. But the person caring for the slave has, according to Pufendorf, no right to the life of the slave, only a right to means to overcome the slave's indolence or a right to chase him away if he is not willing to offer the service in return for which he receives care and sustentation.

The second case is the case of prisoner of war (JNG VI.3.5). According to Pufendorf, there is also a potential for exchange here insofar as the prisoner of war keeps his life and body free from harm in exchange for being bound to obedience (JNG VI.3.6). If the prisoner of war engages in such a relation

\footnotetext{
${ }^{27}$ I am only sketching here some important issues without to claim a comprehensive account on this subject. For a sustainable work on that, see Simone Zurbuchen, "Dignity and Equality in Pufendorf's Natural Law Theory", in: Philosophy, Rights and Natural Law, ed. Ian Hunter and Richard Whatmore, Edinburgh 2019, pp. 147-168.
} 
of exchange, according to Pufendorf, he leaves the status of prisoner and becomes a slave. But if the prisoner does not engage in such relation of exchange and keeps his attitude of hostility, then he would not obey and would remain in the state of war, which is a state of force and violence (JNG VI.3.6). ${ }^{28}$ The difference between the prisoner who remains a prisoner of war and a prisoner who becomes a slave is the former's lack of recognition of debt and the latter's willingness to recognize a relation of obligation due to the command of the conqueror.

We see that in both cases, it is the free will of the person which leads to engagement in a contractual agreement of exchange. In the first case, the engagement in such a relation enables the person to avoid harm resulting from their own indolence and fatuity. In the second case, the engagement in such a relation enables the person to avoid harm from their enemy and conqueror. It is a free consideration in view of a necessity. But the crucial question is how such free consideration could lead to the loss of rights and moral value and how far such loss could reach, especially in the case of slavery. According to Pufendorf, natural law requires us to respect all human beings as naturally equal in having the moral status of a person (OHC I.7). But at the same time, Pufendorf not only admits the reality but also legitimates the possibility that someone can become a slave by contract and obtain in this way the moral status of an object of property, even if in this case, the ownership of a slave could not be compared with that of an object which could be sold to another person (VI.3.7). For the owner of a slave is not able to sell the person but merely gains the right to command the person. Such a right to command implies, according to Pufendorf, a right only to the service of the person but not to the person itself or to their life or property (JNG VI.3.7). In the case that an owner of a slave treats a slave as an object of property, they are acting inhumanely (JNG VI.3.7). This implicitly refers to low capability of the owner of the slave to live in society with others which could therefore directly impair his social esteem. Pufendorf even seems to appeal to civil law to prevent possible inhumanity and especially to prevent violation of natural rights in such cases where a person (an owner of a slave) demands the right to the service of another person (of a slave) due to the existing debt of this person (of the slave) (JNG VI.3.8).

\footnotetext{
${ }^{28}$ Pufendorf is considering here only the debt which a prisoner of war incurs his life and body being kept free from harm. He is not commenting on the implications of the difference between the just and unjust war, like Locke does. For a general discussion of the advantages of Locke's discussion of the relation between war and slavery in opposition to Pufendorf's more extensive idea of the possibility of slavery, see Bernd Franke, Sklaverei und Unfreiheit im Naturrecht des 17. Jahrhunderts, Hildesheim 2009.
} 
According to Pufendorf, slavery is thus only possible as a relation of discharging an existing debt and slaves maintain their dignity as human beings and the moral status of a person able to be obligated. We saw that, according to Pufendorf, it is impossible to enforce a person to unfree labor since a person is always free to refuse to do so, as in the example of the prisoner who remains prisoner of war instead of leaving the state of war and of becoming a slave. Pufendorf is not trying to excuse or to legitimate slavery; rather, his aim seems to be to demonstrate that enforced slavery is impossible within the framework of natural law and that every injury of natural law in regard to slavery should be prevented by civil law. And it is the cruel owner of slaves who is vulnerable in regard to the possibility of loss of moral value, since he belongs to those who harm the principle of human society.

\section{Conclusion}

Pufendorf presents in his moral theory a clear foundation for moral value and moral estimation - the free will insofar it is ruled by reason. There are two different perspectives to analyze moral normativity in the way Pufendorf claims it as an imposition on the free will of human being: (1) the epistemological perspective regards the obligated person by natural law, which includes an analysis of the subjective accomplishments of a human being to achieve the moral status of a person; (2) the ontological perspective of the institutional frame in which obligation should be thought, which includes the role of a command of a superior. Pufendorf seems to prioritize the former and to consider the latter to be derived from the former. Considering this analysis of moral normativity in Pufendorf, the question of moral value and moral estimation reveals neglected aspects of Pufendorf's theory. Pufendorf seems to claim in regard to the highly problematic and inhumane theoretical discussions of slavery (1) the dignity of human nature as inalienable and (2) the necessity of limitation of arbitrariness in human relations and prevention of harm on natural rights. 